\title{
Watery Entanglements in the Cypriot Hinterland
}

\author{
Louise Steel \\ Faculty of Humanities and Performing Arts, University of Wales Trinity Saint David, Lampeter SA48 7ED, \\ Ceredigion, Wales, UK; 1.steel@uwtsd.ac.uk
}

Received: 21 August 2018; Accepted: 3 September 2018; Published: 5 September 2018

\begin{abstract}
This paper examines how water shaped people's interaction with the landscape in Cyprus during the Bronze Age. The theoretical approach is drawn from the new materialisms, effectively a 'turn to matter', which emphasises the very materiality of the world and challenges the privileged position of human agents over the rest of the environment. The paper specifically moves away from more traditional approaches to landscape archaeology, such as central place theory and more recently network theory, which serve to separate and distance people from the physical world they live in, and indeed are a part of; instead, it focuses on an approach that embeds humans, and the social/material worlds they create, as part of the environment, exploring human interactions within the landscape as assemblages, or entanglements of matter. It specifically emphasises the materiality and agency of water and how this shaped people's engagement with, and movement through, their landscape. The aim is to encourage archaeologists to engage with the materiality of things, to better understand how people and other matter co-create the material (including social) world.
\end{abstract}

Keywords: Cyprus; Bronze Age; water; materiality; new materialisms; entanglements; assemblages; networks; central place theory

\section{Introduction: A New Materialist Approach to Past Environments}

This paper seeks to evaluate how the agency of water shaped the development of the Cypriot landscape during the Bronze Age, focusing on how the natural world itself shaped peoples' engagement with their environment. It draws upon the new materialisms [1-3], a theoretical perspective that is gaining traction within the wider social sciences, including archaeology. This approach, which is embedded in what Fox and Alldred (p. 3) describe as a 'turn to matter' [4], seeks to move beyond anthropocentric discussions of people's responses to, and manipulation of, the natural environment; instead, it considers the complex relations between people and place from a perspective which acknowledges the agency of matter (in this case, water). Embracing such an approach is, I would argue, fundamental for our understanding of past environments and landscapes; these were not simply shaped by people's actions, inscribing their will upon a passive and inert natural world. Instead, it contends that humans are simply one of the myriad things/matters that emerge to coproduce the material world.

For archaeologists who are primarily engaged in trying to piece together human action from the archaeological record, this approach is challenging, upturning as it does our understanding of the human agent's relationship with matter, seemingly foregrounding the physicality of the archaeological record, and in particular, environmental data. In fact, the new materialisms attend not only to nature and the environment, but also the place of embodied humans within the material world. They provide us with new ways of thinking about the archaeological record, exploring the transformative role played by matter in the creation of past material and social worlds. At the same time, it acknowledges humans were entangled within, and indeed part of, these material worlds: they coproduced it through their actions, but were likewise constrained by the very physicality of the matter and substances 
with which they interacted. This shift in perspective actively embeds humans within the material environment, and draws attention to how human agency is constituted by the matter with which it engages. This is a recursive relationship: matter equally responds to, acts with, and even directs human agency, both enabling and provoking certain responses from the human actor. Therefore, although this approach questions the dominant, privileged position of human agents, it does not advocate that we cease searching for people and their actions within the archaeological record. Indeed, the new materialisms perspective potentially provides a middle ground between empirical, science-based archaeologies and social archaeology [5], bridging the intellectual gap that has developed between studies of the environment and artefacts: the former traditionally as a resource to be exploited and mastered, and the latter as objects created by, belonging to, and imbued with meaning by people.

\section{Central Places, Networks, or New Materialisms? People in the Landscape}

In this paper, I address the interactions of people with, and within, the Bronze Age landscape of Cyprus. Previously, archaeological studies of settlement and landscape have drawn upon central place theory and network theory. Central place theory [6] looks at political and economic relationships of settlements within a wider rural territory, specifically identifying locales that serve as the economic, sociopolitical, and ideological hub. There is an understanding that these are urban in character and have a centralised administrative role, such as the collection of taxes. Jimenez and Garcia (p. 85) [7] provide us with several criteria for the archaeological identification of a central place. This should be the largest site in the region, dominating it administratively, economically, and physically (presumably through ideological and/or military force); it is the seat of a ruling class/elite and is thus associated with centralisation of specialised production; there should also be evidence for increased economic and social diversification at this locale. It is worth noting that these criteria fit within hierarchical models for settlement and social organisation and perhaps are not easily applicable across all cultural settings. Alternative models of settlement organisation—such as heterarchy [8,9], which allows for urbanisation without imposing a top-down power structure on the archaeological record-might provide a better understanding of inter- and intrasite relations, as for example, Keswani's [10] analysis of Late Bronze Age settlement on Cyprus and Schoep's [11] discussion of Middle Minoan II Malia. Another model, which takes account of increasing social stratification in a nonurbanised society, has been developed by Frangipane [12] to explain the architectural and social complexities evident in fourth-millennium Arslantepe in eastern Anatolia. These approaches are helpful for understanding the apparent centralization of workshop activities and storage at Erimi Laonin tou Porakou [13].

Meijers (p. 245) notes how "the central place model has had increasing difficulties explaining spatial reality", in part because of the inevitable hierarchical structure, but also because it does not fully take account of the relationality of settlements within a landscape or territory [14]. He instead proposes a network model of spatial organisation. Network theory focuses on the interconnections between nodal points; these might, for example, be thought of as social entities (people), objects, or as places in a landscape inhabited or otherwise used by people. Network theory moves the perspective away from the nodes (e.g., central places and other sites) to the connections between them (e.g., movements or flows of people, material culture, knowledge, etc.). As Collars et al. note (p. 5-6), it is these relationships between peoples, things, and/or places that constitute the structure of a network and are thus important [15]. Most archaeological applications of network theory have tended to focus on the interactions between people and things [16], largely drawing upon Latour's actor network theory [17], but there have been some studies on the connectivity and intervisibility of sites. For example, archaeologists have explored connections between localities using proximal point analysis [18], which considers the physical relations between sites by marking these as points on a map and linking each one to its three closest neighbours-a method employed to great effect by Broodbank to explore seafaring networks within the Cycladic archipelago during the Early Bronze Age [19] and more recently by Collar to the Jewish Diaspora of the first and second centuries A.D. [20]. Proximal point analysis, however, does not take into consideration the physical composition of 
the landscape (mountainous terrain, waterways, etc.) and how people actually move through it; instead, the assumed interconnections are simply plotted as straight lines as the crow flies onto a two-dimensional map. In a more recent application of network theory, Brughmans et al. (p. 65) explore long-term changes in visibility patterns between settlements in Iron Age and Roman southern Spain [21]. As with the proximal point analysis, the settlements are represented as nodal points; however, here the focus is on the relationality (in this case, the intervisibility or lines of sight) between these nodes, which is represented as arcs (directed edges) between two sites. This approach takes into consideration the physical configurations of the landscape- -high ground, waterways, etc.-and thus how people might have moved through and interacted within it.

In this paper, however, I argue that central place and network theory are both problematic because they privilege the position of the human in their environment, and as a corollary, they separate and distance people from the material world. These approaches, at best, obscure the environment; rather than embedding people within (and as part of) it, these perspectives place people like an overlay onto the landscape. It assumes that people move across and manipulate the natural world, which is defined as passive, inert, and waiting for human action to give it meaning. While phenomenologically-informed landscape archaeologies contend that it is human action that creates places [22], that people move through the land and inscribe it, but they are not part of it, a new materialist approach situates people both in and as part of the landscape, acknowledging them as one of many agencies of matter. It recognises peoples' innate materiality, that they are part and parcel of the flows of agency in what Barad (p. 817) describes as 'an ongoing open process of mattering' [23].

The new materialisms likewise emphasise relationality between entities/matter, for example, through the concept of assemblages (or agencement). An assemblage is the coming together and interactions of a heterogenous and nonhierarchical group of entities described by Bennett (p. 23) as "ad hoc groupings of diverse elements, of vibrant materials of all sorts... living, throbbing confederations" [1], constantly in flux or, as Harris (p. 90) describes, "in a state of becoming" [24]. The constituent parts of the assemblage are multiscalar [25], from the micro (such as microbes and bacteria) to the macro-not simply the human agent or a body of water, but even to the scale of human communities, overarching political systems, even the state, thus illustrating how tangible material entities and the immaterial might cohere to coproduce assemblages [26]. Key to understanding an assemblage is that it, as DeLanda observes (p. 2, my italics), 'actively links these parts together by establishing relations between them' [27]. This relationship is, moreover, recursive; as DeLanda (p. 83) comments, the "properties of a whole are produced by the ongoing interactions between its parts, while the whole ... reacts back on this part" [27]; thus, an assemblage is more than the sum of its constituent parts. The other advantage of assemblage theory is that it automatically allows us to analyse and integrate materials at different scales-from microscopic environmental data, through the individual artefact (even drilling down to the component materials of this object), to the broader geographical scale typically encompassed within landscape archaeologies-and moreover, to consider how these variously interacted with, and were shaped by, the intangible, ephemeral, and immaterial, including thoughts, ideas, and social structures. The challenge of assemblage theory, then, is to think beyond the residual physical remains of the past, instead focus on the ebb and flow of (im)material interactions, and through this to explore relationality in the past.

The relationality of assemblages alludes to entanglements of matter [28] - the "multiple intersections and tangled nature of being" [3]. The approach taken here is distinct from Hodder's perspective on entanglement [29]; Hodder (p. 95) argues that people and things are "entwined, involved with each other, tied together" and impact upon each other; this is framed within a flat ontology, in which people and things (materials and or/objects) are equal and distinct from each other, effectively separating people from the rest of the material world. For Ingold (p. 4), entanglements represent fluxes and flows of matter within "a meshwork of interwoven lines of growth and movement" [30], with no defined point of origin or directionality. In this article, I follow Barad's [28] understanding of entanglement, derived from quantum physics: the understanding that 
there are no fixed entities and that things/phenomena come into being (or gain meaning) through their intra-action; rather than focusing on individual entities (or, in quantum physics, individual particles) separately, it describes the system (social and material worlds) as a whole, taking into account how material agencies emerge and act together. Therefore, rather than trying to impose nodes and (artificial) networks of human activity onto a partially mapped Cypriot Bronze Age landscape, this paper explores human interactions within, and as part of, the matter of the material world through the lens of the new materialisms, emphasising flows and entanglements of matter and thinking about these as assemblages, an approach that is gaining traction in archaeology [31]. As Barad (p. 170) notes:

"Bodies do not simply take their places in the world. They are not simply situated in, or located in, particular environments. Rather, 'environments' and 'bodies' are intra-actively co-constituted. Bodies ('human', 'environmental', or otherwise) are integral 'parts' of, or dynamic reconfigurings of, what is" [28].

\section{The Cypriot Bronze Age Landscape: A Brief Overview}

Discussion of settlement and landscape in Bronze Age Cyprus (Figure 1) have largely been viewed through the lens of resource management, in particular focusing on increasing exploitation of the island's metalliferous zone around the foothills of the Troodhos mountains throughout the third and more so during the second millennium B.C. Nonetheless, the footprint of human activities in Cyprus changed greatly over the two millennia of Bronze Age occupation on the island (Table 1), and, as both Steel [32] (p. 11) and Knapp [33] (pp. 21, 24) have commented, have typically been presented within a cultural-historical framework. Before turning to the watery entanglements that shaped this landscape, I will briefly outline these shifting patterns of settlement. A more detailed analysis of the trends in site distribution and topography in the Early-Middle Cypriot (henceforth) EC-MC period is provided by Georgiou [34].

Table 1. Chronological table for Bronze Age Cyprus (after Knapp 2013, Table 2).

\begin{tabular}{cc}
\hline Cultural Phase & Approximate Date B.C. (Calibrated) \\
\hline Philia facies & $2400 / 2350-2250$ \\
Early Cypriot I-II & $2250-2000$ \\
Early Cypriot III-Middle Cypriot II & $2000-1750 / 1700$ \\
Middle Cypriot III-Late Cypriot I & $1750 / 1700-1450$ \\
Late Cypriot IIA-Late Cypriot IIC (early) & $1450-1300$ \\
Late Cypriot IIC (late)-Late Cypriot IIIA & $1300-1125 / 1100$ \\
\hline
\end{tabular}

The Philia facies, which marks the transition to the Early Bronze Age, is characterised by the establishment of new settlements in the central and western Mesaoria, around the edges of Troodhos mountains, and along the north coast. Some, therefore, were in close proximity to the island's copper deposits, near good agricultural land, and/or with access to the sea [35]. There are small shifts in settlement pattern throughout the longue durée of the EC-MC period. Some sites have evidence of successive layers of occupation: such as Marki Alonia from the Philia phase to MCII [36] and Politiko Troullia [37] from EC II-MC III (based on the pottery), while others, such as Sotira Kaminoudhia [38], were only occupied during the EC period. There is, however, a rise in the number of settlements in the MC period, with the establishment of new sites such as Erimi Laonin tou Porakou [39], suggesting increasing population, probably due to the use of traction animals and land clearance resulting in improved arable production. Until recently, our knowledge of EC-MC settlement was largely derived from the associated cemeteries, but over the past twenty years or so, there has been extensive excavation of a number of key sites. Settlements were frequently extensive, covering some 15 and 20 hectares, and many were located on a low plateau, close to good arable land and a water supply [40]. Clusters of settlements occur in particular geographic zones, such as along the northern coastal plain and around the northwestern foothills of the Troodhos massif, especially at the interface of the arable land and the mineral-rich lower reaches of the Troodhos. Moreover, recent excavations at Kissonerga Skalia [41] 
and Prasteio Mesorotsos [42] have filled an apparent gap in EC-MC occupation in the southwest of the island.

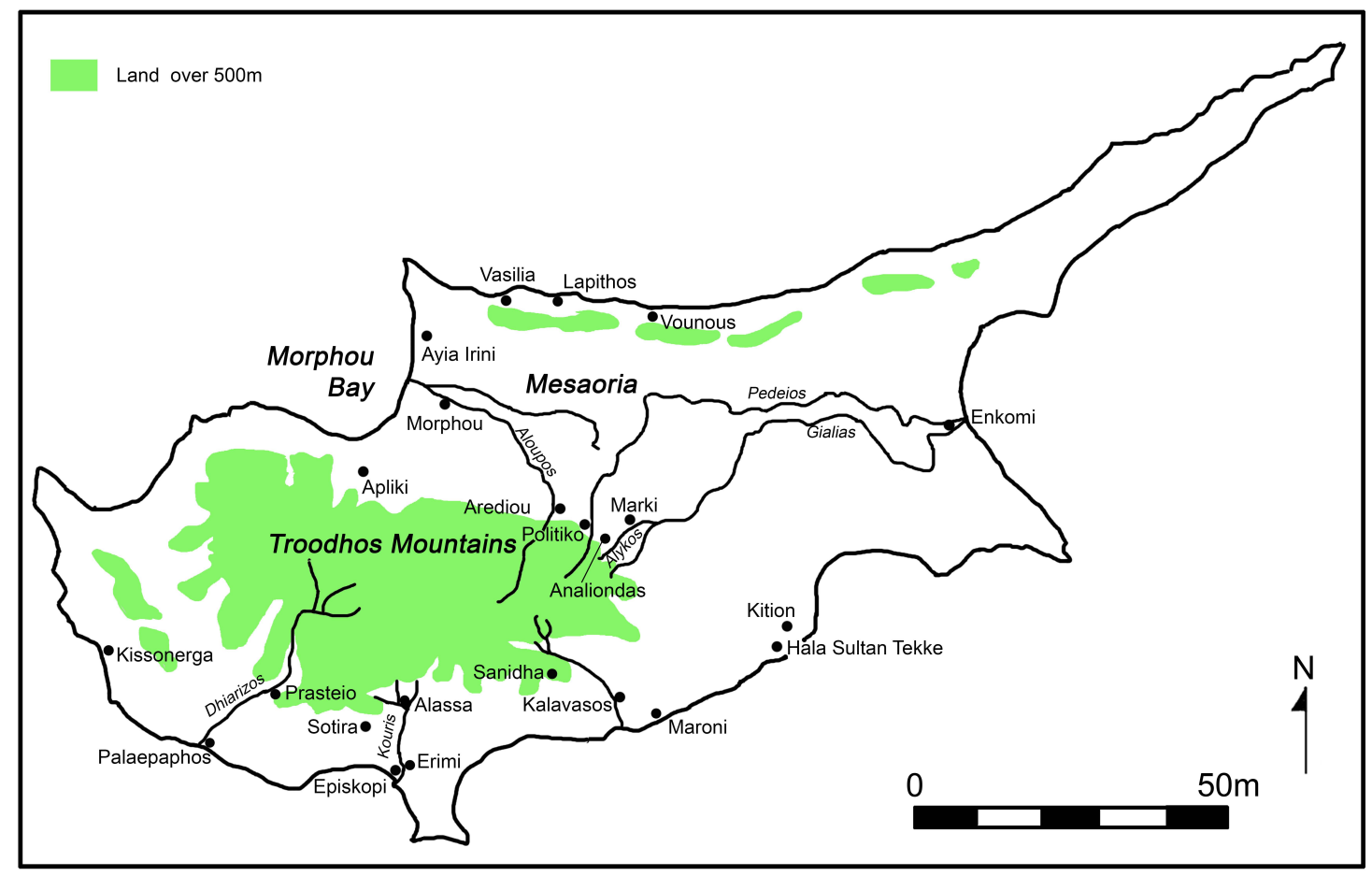

Figure 1. Map of Bronze Age Cyprus, indicating sites and rivers mentioned in text.

Although regionality has been explored [43,44], largely through variable patterns in the geographic distribution of pottery, there has been less emphasis on relationships (networks or assemblages) between the EC-MC communities within their wider landscape. Detailed survey and excavation work at Politiko Troullia, however, has looked at the relationship between the site and its surrounding environment, revealing intensive agrarian exploitation of the landscape, but an apparently otherwise isolated farming community [45]. In this issue, Webb examines the relationship between site location, economic resources (especially copper), and their exploitation in the political economy in the island's narrow northern coastal strip: identifying Vasilia, Vounous, and Lapithos as significant nodes (or central places?) in networks linking inland copper-producing sites with international maritime networks [46].

The LC period (later second millennium B.C.) is characterised by increasing diversification of landscape use, resulting in a progressively complex settlement hierarchy and the establishment of urban centres [32]. By the 13th-14th centuries, an interrelated system of sites covered the coastal plains and the inland river valleys up to the cupriferous hilly flank zones. There has been more consideration of how LC settlement was situated within an economic landscape and, to some extent, the relationality between urban sites and the hinterland, which Priscilla Keswani has explored within a staple-wealth finance model [47]. Originally, Catling (pp. 142-143) [48] suggested a tripartite settlement hierarchy comprising the coastal (trading) urban centres and inland farming and mining sites. Knapp $[49,50]$ and Keswani [10,47] have both refined Catling's model, suggesting a more complex pattern of settlement use. This comprised substantial primary (urban) centres located in the coastal plain such as Enkomi, Kalavasos, and Morphou [32,33]—some dominated by imposing ashlar buildings, which possibly functioned as administrative/taxation centres-and secondary and tertiary centres in the hinterland. These "centres" were supported by numerous smaller specialist sites primarily in the hinterland, only a handful of which have been excavated. Some, such as Arediou Vouppes [51,52] and Analiondas Palioklichia [53], were associated with arable farming; others, such as Apliki Karamallos [54] and Politiko 
Phorades [55], with primary copper production or pottery manufacture, as at Sanidha Moutti tou Ayiou Serkou [56]. In many ways, although not articulated as such, these settlement models conform to central place theory, as discussed above. Moreover, although archaeologists have not applied network theory to examine the interrelationship between these sites, both Keswani and Knapp [47,57] have considered the economic relationality between sites, for example, from a staple/wealth finance perspective.

This discussion of changing patterns of human occupation throughout the Cypriot Bronze Age provides us with a base point for considering the peoples' interactions with the environment; as noted above, these models layer human action onto a passive landscape, upon which they manipulated resources and created meaningful place from "empty" space [58]. In these narratives, therefore, people are detached from the environments they inhabit. The following discussion, however-which draws attention to the agency of water and suggests various watery-human assemblages-seeks to embed humans in their landscape, to better understand how the archaeological record described above might have been lived and experienced.

\section{Watery Entanglements in the Cypriot Hinterland}

I want now to consider how the agency of water shaped peoples' interactions with and within the environment in Bronze Age Cyprus. First, we should consider the essential materiality of water. We cannot exist without water [59]; some $55 \%$ to $60 \%$ of the matter of our bodies is made up of this substance [60] and equally it sustains the plant and animal life on which we depend. This, then, is the first of our assemblages: our bodies, the water we ingest, and the foodstuffs sustained by this substance that we consume. The process of consumption is an assemblage; we are made of and interact with water on a daily basis to survive. Water, therefore, is central to our relationship with the environment [61]. However, water does not survive as a meaningful, measurable entity in the archaeological record, but instead is transient and ephemeral, tending to trickle away or evaporate, especially in the arid lands of the Near East. Instead, archaeologists have to focus on the residual remains of human interactions with water, identifying hydraulic technologies [62] such as drains, wells, cisterns, and aqueducts. While these are regularly recorded within excavation reports, within Cypriot archaeology, there has been little consideration of how these were actually integrated within daily practices within and beyond the household [63].

As Knitter et al. [64] (p. 4) note, proximity to fresh water sources is one of the key factors determining the very location of human habitation, because it is a constant, daily requirement for survival, necessary for daily household needs such as drinking, cooking, and cleaning. Beyond the immediate requirements of the household, water had an increasingly important economic value as societies become sedentary throughout the Neolithic and Bronze Age, and as people increasingly settle at fixed points in the landscape, supporting arable farming and livestock, as well as being used in various forms of industrialised processing, including pottery production, working textiles, and metallurgy. Indeed, Strang has suggested that as communities become more hierarchically organized, water is increasingly contested as an economic asset; this is characterised by ever more complex hydraulic technologies, such as cisterns, communal wells, and drainage and sewerage systems, which are centrally organised. While the building and maintenance of these waterworks tend to be a male concern, Strang notes that the physicality of water collection typically continues to be women's work [65].

The presence of reliable water sources, such as perennial springs and rivers (Figure 2), therefore, provided desirable places for occupation for Cypriot communities throughout the Bronze Age, which developed into the settlement nodes and/or central places picked up in archaeological survey. However, as Attala (p. 80) reminds us, water is not simply "an inert material or resource serendipitously available for human consumption" [66]; its specific properties and capacities constrain the ways in which people can interact with it $[67,68]$. In its liquid state, water resists our attempts to handle and manipulate it, trickling through fingers and cupped hands, evaporating and "disappearing" into thin air. Strategies developed to control and constrain this ephemeral substance include holding it in pools, 
cisterns, wells, and reservoirs; it can be moved around and distributed in portable containers (jugs, buckets, bottles, etc.); and its liquid capacity to flow allows it to be channelled around and between sites, through pipes and drains, and along viaducts.

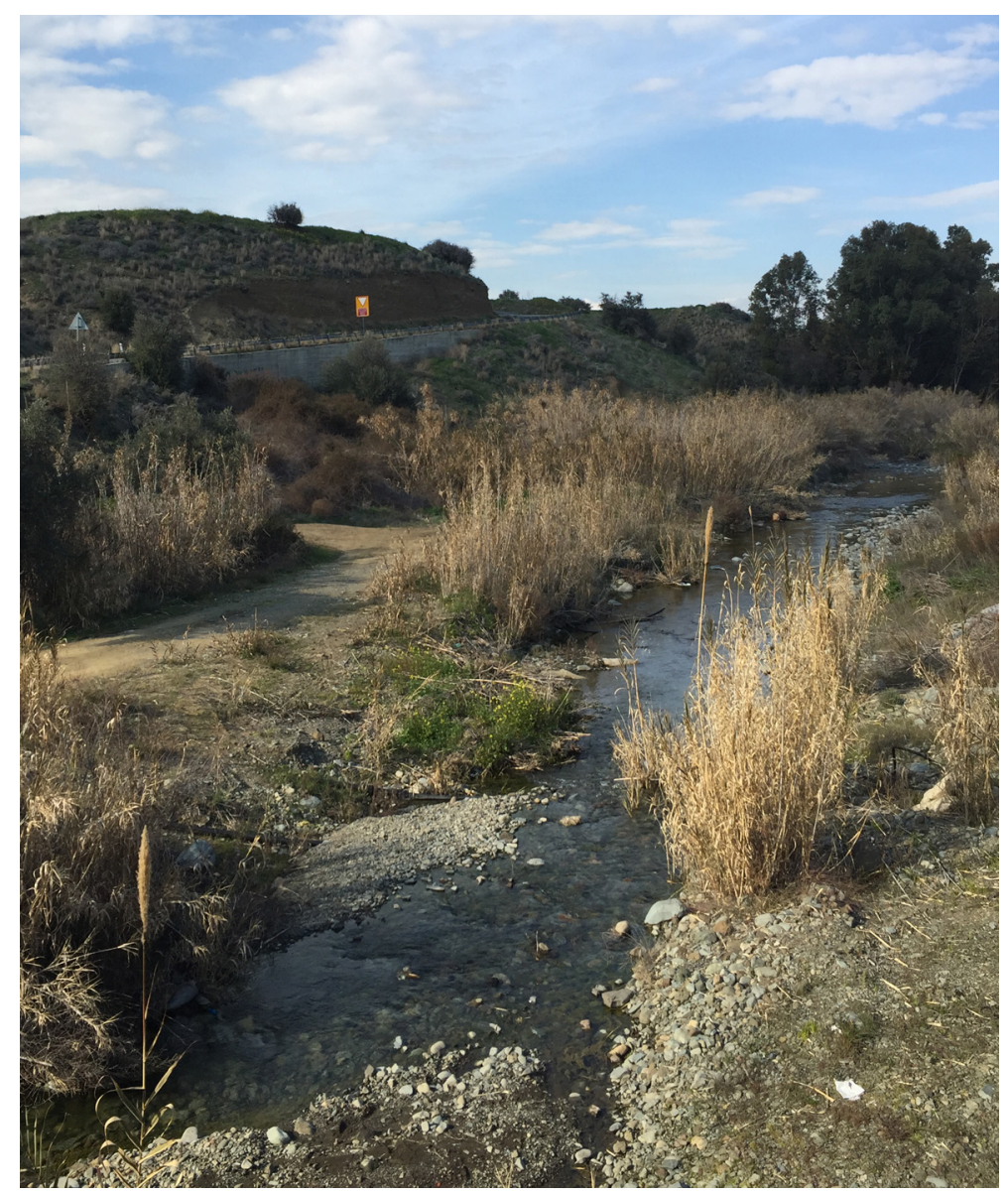

Figure 2. Water flowing in the Koutis river, tributary of the Aloupos, near Arediou. Photo: L. Steel.

The earliest wells identified on Cyprus, at Kissonerga Mylouthkia, date to the mid-late ninth millennium calibrated B.C., in what has been termed the Cypro-PPNB (Cypro-Pre-Pottery Neolithic B) [69], and were dug by the earliest settled farming communities on the island. These wells demonstrate a sophisticated understanding of water, being dug into the havara bedrock deliberately to intersect underground streams [70]. Intriguingly, these skills and knowledges appear to have been lost by the later prehistoric inhabitants of the island, and there is little extant evidence for water management in the EC-MC villages excavated: no wells or cisterns have been identified, nor any drains for channelling excess rainwater. An interesting series of basins and water channels carved into the limestone bedrock has been identified at MC Erimi Laonin tou Porakou [71], part of a workshop complex, indicative of increasing knowledges of handling, moving, and storing water and perhaps an early attempt to control this (economic) resource. I have suggested elsewhere that people's primary engagement with water occurred outside the settlement, presumably on the banks of the nearby water source, and that this would have been brought into the settlement in portable containers, possibly to be stored in pithoi [64]. Containers used to carry water into the settlement might have been pottery jugs, which are plentiful in EC-MC settlements, or otherwise made from perishable materials such as leather or plaited basketry, as suggested by ethnographic analogy [72]. Daily activities would include collection of water for drinking, cooking, and cleaning. Unfortunately, while the settlements have been well excavated and published in detail, their associated water sources have not been the focus of fieldwork; moreover, these were ephemeral activities, which would have left little archaeological trace. 
In the Late Cypriot (henceforth) LC period, however, there is a very different level of engagement with water within the settlement, reflecting increasing emphasis on it as an economic resource. Wells and cisterns have been excavated at a number of sites, physically anchoring sites in the landscape. Rather than following water where it flowed, this substance was tamed and contained within the settlement and peoples' activities were fixed accordingly. The wells were usually located inside individual buildings, households in the urban centres, and at the agricultural settlement of Arediou (Figure 3) in a small room attached to a well-built barn. I have previously noted (p. 522, n. 71) that communal water places, namely wells in open spaces within the settlement, have only rarely been identified [53], which I argue is indicative of the economic importance of water and consequently a will to control access to this resource. Drainage systems were also developed, to allow run-off of heavy rainfall during the winter months. These hydraulic technologies largely parallel those identified by Calvet in Late Bronze Age Ugarit [73,74], pointing to the introduction of new practices from the northern Levant. There is no evidence, however, that water management was centrally controlled in the LC towns: there was no systematised drainage system removing waste water from houses, nor any provision for piping clean water around the settlement. Instead, water management remained at the level of the household. Elaboration of water systems, possibly apparently associated with bathing, is evident in a small number of monumental buildings in the major urban centres. The earliest, dating to the 14th century B.C., is the so-called Basin Building at Maroni Vournes, which comprises a large sunken basin lined in stone, which the excavator (p. 16) has compared to a Minoan lustral basin [75]. Hitchcock (p. 12) also draws attention to the elaboration of a 12th century bathroom in House A at Hala Sultan Tekke, with a sunken basin paved and lined in ashlar masonry, the interstices of the paving lined with a lead waterproof filling [76]. There are also elaborate drainage facilities attested in Building II at Alassa Paliotaverna, compared by the excavator (pp. 434-435) to the water systems in the Palace of Knossos [77]. Although these examples clearly demonstrate considerable skills in working with water, this was not made available to the wider community, but remained inside (and controlled by) what might perhaps be considered to be elite households. Nonetheless, we can see that human-water interactions were transformed in the later second millennium. Water had become an urbanised resource, something that could be owned, controlled, manipulated, spatially confined, and, in a sense, dominated.

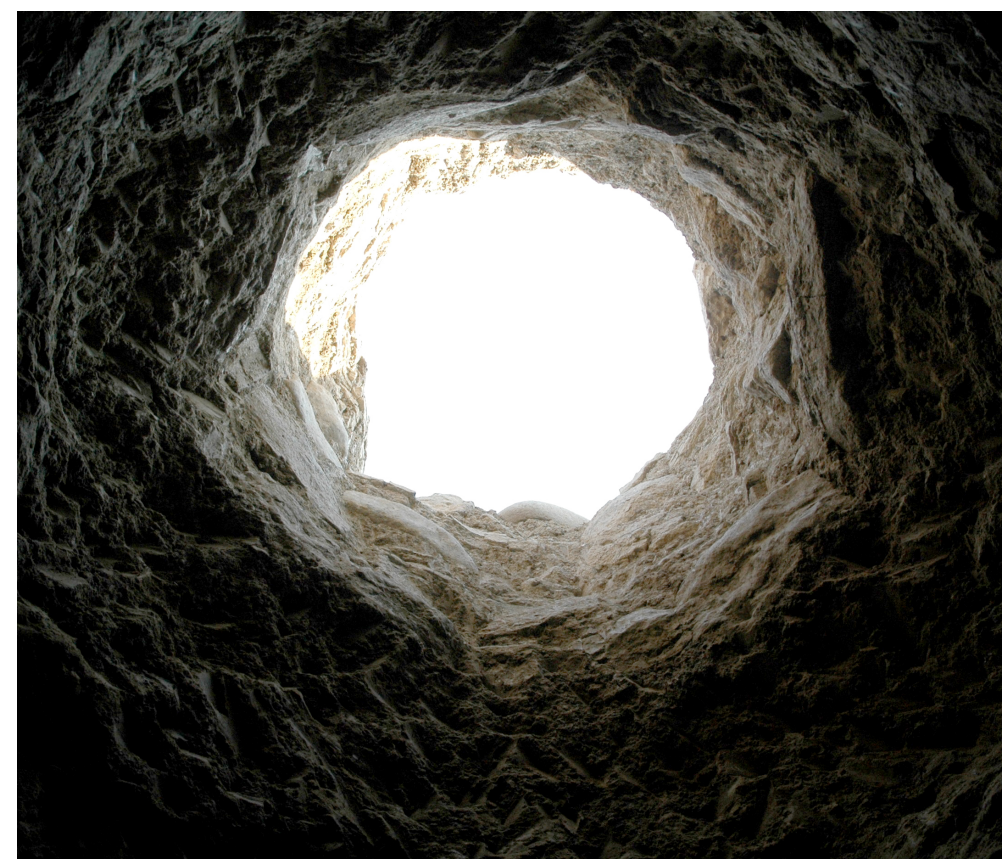

Figure 3. LC well in Building 2, Arediou Vouppes. Photo: S. Thomas. 


\section{From Networks to Assemblages}

Returning to shifting inter-site relations in the Cypriot landscape during the Bronze Age, we will now look at the island's river systems. Traditional landscape studies might consider the relationality facilitated by the waterways as interconnecting networks (see above). The following discussion, however, will focus on multiscalar assemblages, from a single object (a boat) to the settlements identified through survey and excavation. As noted above, the location of Bronze Age settlements was predicated by access to a secure water supply and good arable land, able to support the populations of villages and towns. Drawing upon Devillers' detailed geomorphological study [78], Michael Brown has made the case that the waterways of eastern Cyprus were at least partly navigable during the Bronze Age [79]. The Alykos-Gialias-Pedieos river system was particularly important for movement east-west traversing the Mesaoria plain and connecting sites on the east coast with the cluster of settlements scattered around the northern edges of the Troodhos [80]. Other rivers radiating from the Troodhos mountains plausibly connected the interior directly down to the coast, at least during the wetter part of the year; for example, the Aloupos river in the northwest linking the Politiko-Arediou cluster of sites with Morphou Bay [81] and the Kouris river linking Alassa and Episkopi; moreover, if dry in the summer months, the riverbeds would provide an easy route for travel on foot or with pack animals. These rivers did not provide connectivity across the landscape, which would have been negotiated on foot (or by wheeled transport?) over the flat coastal plains; however, the extensive rugged terrain of the Troodhos mountains effectively cut the southwest coast from the rest of the island, with a largely impassable limestone plateau plunging into the sea between Episkopi and Palaepaphos (Figure 4), and by necessity, the settlements in the southwest would have communicated with the rest of the island by seagoing vessels hugging the coastline. Although there is no evidence for built harbours, Knapp (pp. 84-85) notes that several potential harbourages have been identified along the south coast between Palaepaphos and Hala Sultan Tekke [82].

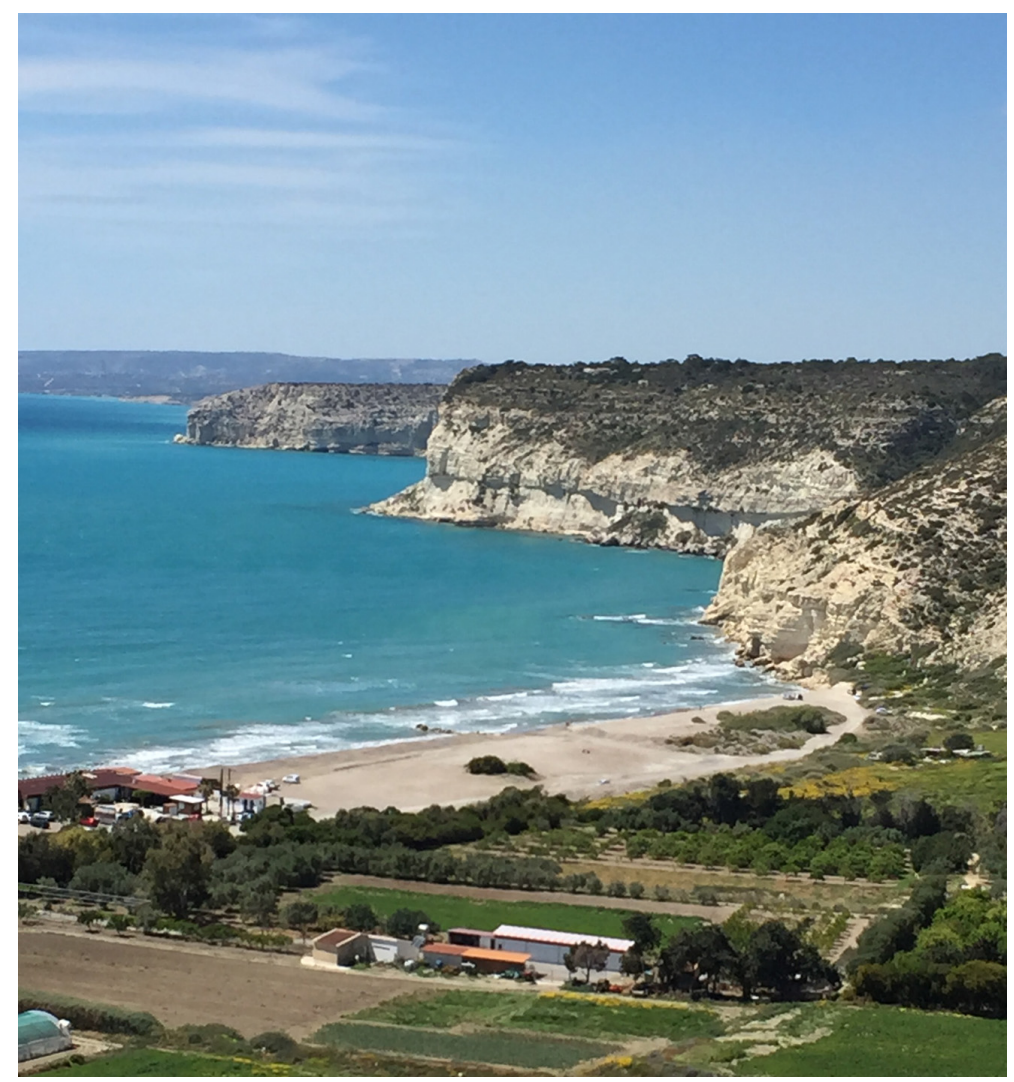

Figure 4. View from Kourion of limestone plateau and cliffs. Photo: L. Steel. 
Although the boats used to navigate these waterways and the shallows of the Cypriot coastline have not survived, we might suggest their existence from occasional models crafted from clay, the earliest which seem to represent rivercraft, although Knapp (p. 82) [82] expresses some reservation whether these early models do in fact represent boats. Wachsman (pp. 62-64) [83] has suggested that the earliest of these, a Red Polished model, as well as a small number of MC White Painted boat models, probably represented coracle-like vessels or basket-boats, the incised and painted network designs perhaps indicating the basketry framework. The example from the Louvre (Figure 5) apparently suggests a vessel of considerable size, which might represent a larger, possibly seagoing, craft [84], although we should note that the traditional Iraqi quffa (or kuphar) could be large enough to hold several individuals and transport goods, building materials, and livestock [85]. There is more reliable evidence for the LC period in the form of three Plain ware models of an apparently more complex watercraft, which Wachsman [83] identifies (p. 66) as a type of spacious seagoing vessel, or merchant ship of indigenous design, and at the end of the LC period, there are graffiti of seagoing vessels on the walls of Temple 1, Kition [82]. Seafaring technologies enabling communication within the wider Mediterranean undoubtedly had spread to the island by the LC period, evidenced by an ever-increasing influx of traded commodities from the Aegean and the Levant, illustrating Cypriot participation in long-distance maritime trade. The importance of seafaring is indicated by the many anchors found in LC coastal settlements and anchorages as well as in the sacred precinct at Kition [83]. The waters of the Mediterranean also brought incomers, merchants visiting the island, settling and bringing with them new objects and knowledge of novel ways of doing things-including writing, seal stones, wheel-made pottery, and monumental architecture [32] - these changes were intrinsically associated with the development of the LC coastal centres and, as Knapp (p. 133) argues, illustrate the emergence of an urbanised and socially stratified society [33], transforming the way of life on the island. I would contend that it was through increased engagement with seafaring technologies and the resulting watery interactions within and beyond the island that such changes were enabled.

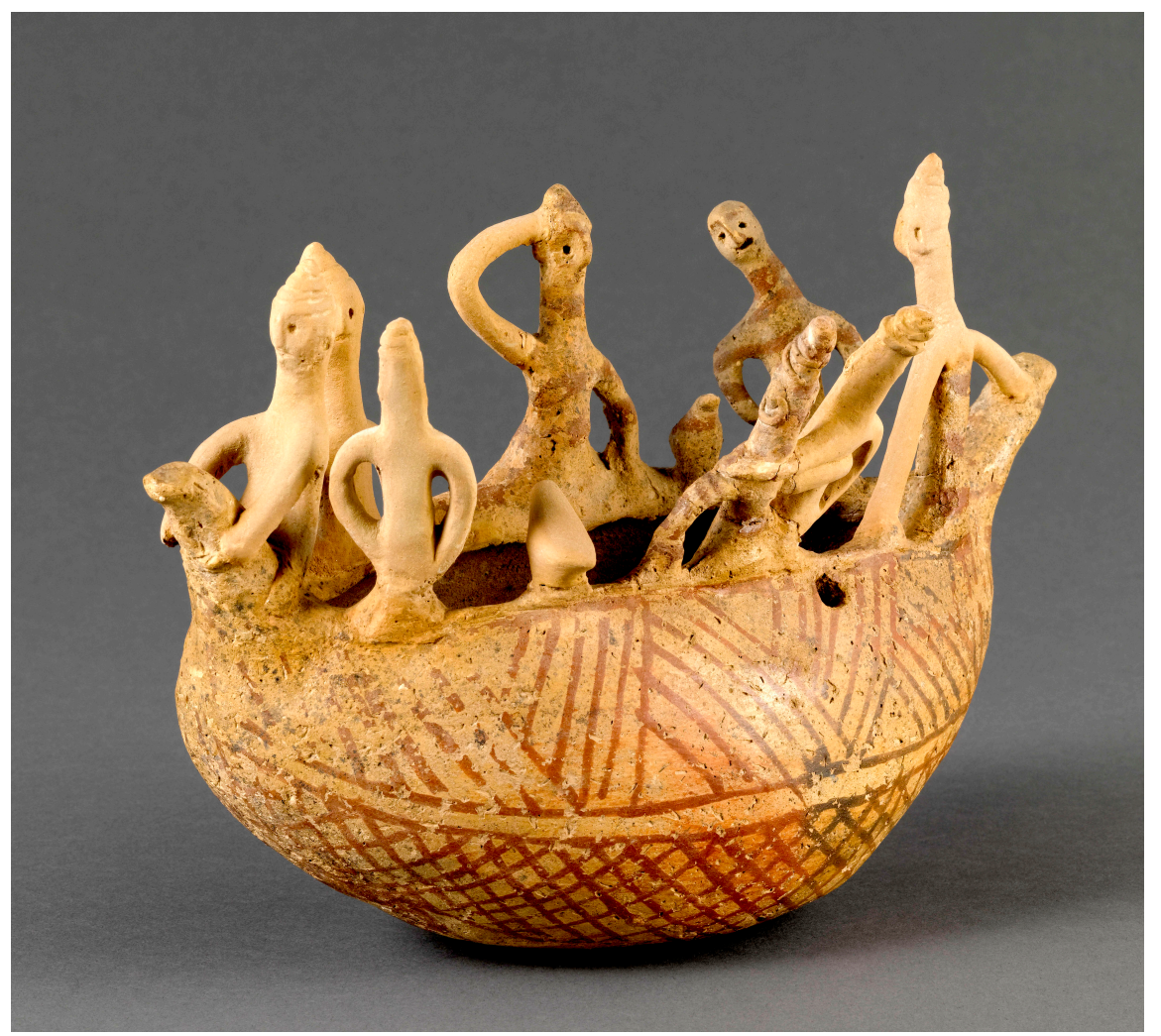

Figure 5. White Painted ware model of boat with crew, AM 972. Courtesy of the Louvre. 
How then can we bring these diverse levels of archaeological data together to explore changing patterns of settlement and inter-site relationality in the Cypriot landscape? First, we might consider the boats as assemblages, the temporary coming together of material and immaterial entities during the process of their crafting. These entities include the materials from which the boats were crafted (including basketry and a waterproof (leather?) covering for the basket-boats, timbers, linen sails, twine for ropes, bitumen, etc. for seagoing vessels), the capacities of these materials informing the haptic skills of the craftsmen who procured and worked with them, their intangible knowledge, and the tools that they used. Once complete, these rivercraft and seagoing vessels were incorporated within other assemblages: the waters through which they moved, the crews which manned them, their knowledge of moving safely through water, navigational skills, communication skills as they moved between communities (the archaeologists' nodal points in the landscape), and the cargoes they transported. The relationality of these communities scattered throughout the Cypriot landscape can also be considered as multiscalar nested assemblages, comprising myriad interwoven connections within connections. The boats themselves comprise an assemblage with their own emergent properties. These were then incorporated within larger assemblages: the waterways, settlements, and their communities comprise diverse material and immaterial elements coming together, comingling and interacting, and the processes by which the diverse entities came together in turn created new (im)material connections. Water therefore facilitated the spread not just of goods and materials between communities (copper, finished metal artefacts, pottery, and textiles might all have been traded), but likewise, the movement of people inevitably entailed the sharing of ideas, news, knowledge, and new ways of doing things. We should not, however, discount terrestrial movement with pack animals, wheeled transport, and on foot as other assemblages, perhaps moving along dry riverbeds in the summer months, thereby again benefitting from the agency of water. Thus, the village and urban communities of the Cypriot landscape, and the social structures within them, emerged from the relationships within these multiscalar assemblages and, I would argue, the material agent bringing together these entities was water. This substance both provoked and enabled activities on the part of the human agents in the assemblage and ultimately shaped the Cypriot landscape.

The very establishment and continued growth of the EC-MC large village communities in the foothills of the Troodhos therefore was enabled by these sustaining and interconnecting waterways, as was the later development of the coastal LC towns, which traded Cypriot copper and other goods and commodities produced in the hinterland beyond the island. These waterways connected communities, bringing inland and coastal communities together, facilitating the movement of people, livestock, raw materials such as copper, finished goods, and ideas over considerable distances in the Cypriot interior north of the Troodhos foothills, in a wooded landscape (as illustrated by charcoal analyses from Politiko Troullia) [86], which might thus have been impassable or at least difficult to negotiate on foot. Furthermore, understanding the importance of waterways for communication also allows us to envisage the riverside by the settlements as lively, bustling, and exciting places, with people (family, friends, strangers) coming and going, bringing with them goods, news, and ideas.

\section{Conclusions}

This paper considers the changing shape of the Cypriot landscape throughout the Bronze Age, transformations that have typically been presented within a cultural historical framework, identifying urbanisation in the later second millennium BC with greater social complexity and, above all, increased exploitation of the island's copper resources. Notwithstanding, I have sought to demonstrate the value of the new materialisms for interpreting the complexities of the archaeological record. Specifically, I have focused on how water and people were entangled in ever-changing assemblages and thus how the agency of water shaped peoples' interactions within the environment.

In contrast to traditional landscape archaeologies, which present space as passive and inert or as nodal points and central places marked on a two-dimensional map, and which are only ascribed meaning (becoming place) through human action, the new materialisms encourage us to think about 
humans as one of many matters shaping the material environment. Here, I have explored how Bronze Age settlement was not simply imposed upon the Cypriot landscape through human action, but instead was enabled by the presence of water, as were the associated agricultural, pastoral, and industrial practices sustaining these communities. Throughout the EC-MC periods, water remained untamed and peoples' primary interactions with this substance occurred outside the built area of the settlement. By the LC period, however, changing water management systems accompanied the development of larger coastal towns, which I suggest was influenced by increasing contact with the urban communities of the northern Levant. This article also considers relationality between settlements, but moves away from the static lines and arcs of network theory to think about connectivity and relationships as assemblages, which, depending upon the emergent properties of their constituent parts, are always in flux. Assemblage theory allows us to incorporate different levels of archaeological data normally treated separately, from materials to object, to the built environment, and up to the wider landscape. This approach allows us to reflect upon how connectivity and communication between the Cypriot Bronze Age settlements might have been facilitated by water, namely the riverine system. Engagement with waterways and the development of increasingly advanced boating technologies allowed the movement of people, goods, and materials (such as copper) into and around the interior, and by the LC period, beyond the island. Although the aim of this paper has been to highlight the agency of water, we should of course remember that other agents, such as dry riverbeds, pathways, pack animals, and wheeled transport, also played an important role in connecting communities. Ultimately, my aim has been to demonstrate that archaeological sites themselves are not inert, passive points, simply situated or located in a two-dimensional archaeological landscape. Instead, they represent ancient communities, made up not just of people and their built environment, but of many different immanent materials, which variously emerged and acted with and upon each other to dynamically coproduce the material world.

Funding: This research received no external funding.

Acknowledgments: I would like to thank Giorgos Papantoniou for inviting me to contribute to this special issue of Land and to my anonymous reviewers for their insightful comments. This article has grown out of a paper I presented at the Environment, Landscape and Society: Diachronic Perspectives on Settlement Patterns in Cyprus conference in Nicosia in February 2017. I am grateful to Luci Attala for our many lively discussions of vibrant matter, the new materialisms, and the materiality of water, which have informed this paper. I would also like to thank Eloise Govier and Oliver Harris for discussions of the theoretical underpinnings of the new materialisms. I am grateful to Steve Thomas for reading various early drafts of this paper and his insightful comments. Thanks also to the Agence Photographie de la Réunion des Musées nationaux and the staff of the Department of Near Eastern Antiquities in the Louvre for permission to reproduce the image in Figure 5.

Conflicts of Interest: The author declares no conflict of interest.

\section{References}

1. Bennett, J. Vibrant Matter: A Political Ecology of Things; Duke University Press: Durham, NC, USA, 2010; ISBN 978-0822346333.

2. Coole, D.; Frost, S. Introducing the New Materialisms. In New Materialisms: Ontology, Agency, and Politics; Coole, D., Frost, S., Eds.; Duke University Press: Durham, NC, USA, 2010; pp. 1-43, ISBN 978-0822347729.

3. Attala, L.; Steel, L. (Eds.) Body Matters, Exploring the Materiality of the Human Body; University of Wales Press: Cardiff, UK, in press.

4. Eg Fox, N.J.; Alldred, P. Sociology and the New Materialism: Theory, Research, Action; Sage: Los Angeles, CA, USA, 2018; ISBN 978-1473942226.

5. Harris, O.J.T. Revealing Our Vibrant Past: Science, Materiality and the Neolithic. In Early Farmers: The View from Archaeology and Science; Whittle, A., Bickle, P., Eds.; British Academy: Oxford, UK, 2014; pp. 327-345, ISBN 978-0197265758.

6. King, L.J. Central Place Theory; Sage: London, UK, 1984; ISBN 78-0803923249.

7. Jiménez, M.J.; Garcia, C.T. Central places in the post-Roman Mediterranean: Regional models for the Iberian Peninsula. J. Mediterr. Archaeol. 2015, 28, 81-103. [CrossRef] 
8. Crumley, C.L. Heterarchy and the analysis of complex societies. Archaeol. Pap. Am. Anthropol. Assoc. 1995, 6, 1-5. [CrossRef]

9. Brumfiel, E.M. Heterarchy and the analysis of complex societies: Comments. Archaeol. Pap. Am. Anthropol. Assoc. 1995, 6, 125-131. [CrossRef]

10. Keswani, P.S. Hierarchies, heterarchies, and urbanisation processes: The view from Bronze Age Cyprus. J. Mediterr. Archaeol. 1996, 9, 211-250. [CrossRef]

11. Schoep, I. Social and political organization on Crete in the Proto-Palatial Period: The case of Middle Minoan II Malia. J. Mediterr. Archaeol. 2002, 15, 101-132. [CrossRef]

12. Frangipane, M. Fourth millennium Arslantepe: The development of a centralised society without urbanization. Origini 2012, 34, 19-40.

13. Bombardieri, L. The development and organisation of labour strategies in prehistoric Cyprus: The evidence from Erimi Laonin tou Porakou. In J.R.B. Stewart: An Archaeological Legacy; SIMA 139; Knapp, A.B., Webb, J.M., McCarthy, A., Eds.; Åströms Editions: Uppsala, Sweden, 2013; pp. 91-102, ISBN 978-91-7081-253-8.

14. Meijers, E. From central place to network model: Theory and evidence of a paradigm change. Tijdschr. Econ. Soc. Geogr. 2007, 98, 245-259. [CrossRef]

15. Collar, A.; Coward, F.; Brughmans, T.; Mills, B.J. Networks in archaeology: Phenomena, abstraction, representation. J. Archaeol. Method Theory 2015, 22, 1-32. [CrossRef]

16. Knappett, C. An Archaeology of Interaction: Network Perspectives on Material Culture and Society; Oxford University Press: Oxford, UK, 2011; ISBN 978-0198706939.

17. Latour, B. Reassembling the Social: An Introduction to Actor-Network-Theory; Oxford University Press: Oxford, UK, 2005; ISBN 978-0199256051.

18. Terrell, J. Human biogeography in the Solomon Islands. Fieldiana Anthropol. 1977, 68, 1-47.

19. Broodbank, C. Ulysses without sails: Trade, distance, knowledge and power in the Early Cyclades. Word Archaeol. 1993, 24, 315-331. [CrossRef]

20. Collar, A. Re-thinking Jewish ethnicity through social network analysis. In Network Analysis in Archaeology: New Approaches to Regional Interaction; Knappett, C., Ed.; Oxford University Press: Oxford, UK, 2013; pp. 223-245, ISBN 978-0199697090.

21. Brughmans, T.; Keays, S.; Earl, G. Understanding inter-settlement visibility in Iron Age and Roman southern Spain with exponential random graph models for visibility networks. J. Archaeol. Method Theory 2015, 22, 58-143. [CrossRef]

22. Bender, B. Introduction. In Contested Landscapes: Movement, Exile and Place; Bender, B., Winer, M., Eds.; Berg: Oxford, UK, 2001; pp. 1-18, ISBN 978-1859734674.

23. Barad, K. Posthumanist performativity: Toward an understanding of how matter comes to matter. Signs J. Women Cult. Soc. 2003, 28, 801-831. [CrossRef]

24. Harris, O.J.T. (Re-)assembling communities. J. Archaeol. Method Theory 2014, 21, 76-97. [CrossRef]

25. Harris, O.J.T. Assemblages and scale in archaeology. Camb. Archaeol. J. 2017, 27, 127-139. [CrossRef]

26. Hamilakis, Y. Sensorial assemblages: Affect, memory and temporality in assemblage thinking. Camb. Archaeol. J. 2017, 27, 169-189. [CrossRef]

27. DeLanda, M. Assemblage Theory; Edinburgh University Press: Edinburgh, UK, 2016; ISBN 978-1474413657.

28. Barad, K. Meeting the Universe Halfway: Quantum Physics and the Entanglement of Matter and Meaning; Duke University Press: Durham, NC, USA, 2007; ISBN 978-0822339175.

29. Hodder, I. Entangled: An Archaeology of the Relationships between Humans and Things; Wiley-Blackwell: Oxford, UK, 2012; ISBN 978-0470672112.

30. Ingold, T. Bringing Things to Life: Creative Entanglements in a World of Materials; Realities Working Paper 15. ESRC National Centre for Research Methods, 2010; pp. 1-14. Available online: https:/ /www.google.com.hk/url?sa=t\& $\mathrm{rct}=\mathrm{j} \& \mathrm{q}=\& \mathrm{esrc}=\mathrm{s} \&$ source=web\&cd $=1 \& \mathrm{ved}=2 \mathrm{ahUKEwjuvs7j26LdAhUBsCwKHf7HA9EQFjAAegQICRAC \&}$ url=http $\% 3 \mathrm{~A} \% 2 \mathrm{~F} \% 2 \mathrm{Feprints.ncrm.ac.uk} \% 2 \mathrm{~F} 1306 \% 2 \mathrm{~F} 1 \% 2 \mathrm{~F} 0510$ creative_entanglements.pdf\&usg= AOvVaw3YoJQMemumRcPhb2WsDa5I (accessed on 30 August 2018).

31. Hamilakis, Y.; Jones, A.M. Archaeology and assemblage. Camb. Archaeol. J. 2017, 27, 77-84. [CrossRef]

32. Steel, L. Cyprus before History: From the Earliest Settlers to the End of the Bronze Age; Duckworth: London, UK, 2004; ISBN 978-0715631645.

33. Knapp, A.B. The Archaeology of Cyprus: From Earliest Prehistory through the Bronze Age; Cambridge University Press: Cambridge, UK, 2013; ISBN 978-0-521-72347-3. 
34. Georgiou, G.I. The topography of human settlement in Cyprus from the Early to the Middle Bronze Age. Ph.D. Thesis, University of Cyprus, Nicosia, Cyprus, 2006. (In Greek)

35. Webb, J.M.; Frankel, D. Characterizing the Philia facies. Material culture, chronology and the origin of the Bronze Age in Cyprus. Am. J. Archaeol. 1999, 103, 3-43. [CrossRef]

36. Frankel, D.; Webb, J.M. Marki Alonia: An Early and Middle Bronze Age Settlement in Cyprus. Excavations 1995-2000; SIMA 123:2; Åströms Editions: Sävedalen, Sweden, 2006; ISBN 978-9170812187.

37. Falconer, S.E.; Fall, P.L. Household and community behavior at Bronze Age Politiko-Troullia, Cyprus. J. Field Archaeol. 2013, 38, 101-119. [CrossRef]

38. Swiny, S.; Rapp, G.R.; Herscher, E. Sotira Kaminoudhia: An Early Bronze Age Site in Cyprus; American Schools of Oriental Research: Boston, MA, USA, 2003; ISBN 9780897570640.

39. Bombardieri, L. Erimi Laonin Tou Porakou. A Middle Bronze Age Community in Cyprus; Åströms Editions: Uppsala, Sweden, 2017; ISBN 978-91-7081-227-9.

40. Swiny, S. Bronze Age settlement patterns in southwest Cyprus. Levant 1981, 13, 51-87. [CrossRef]

41. Crewe, L. An appearing Early Bronze Age in Western Cyprus. In Structure, Measurement and Meaning. Studies on Prehistoric Cyprus in Honour of David Frankel; SIMA 143; Webb, J.M., Ed.; Åströms Editions: Uppsala, Sweden, 2014; pp. 137-150, ISBN 978-91-981535-1-4.

42. McCarthy, A.P. Landscape resources and site longevity: Prasteio Metsorotsos and the Dhiarizos valley in prehistory. In Structure, Measurement and Meaning. Studies on Prehistoric Cyprus in Honour of David Frankel; SIMA 143; Webb, J.M., Ed.; Åströms Editions: Uppsala, Sweden, 2014; pp. 15-25, ISBN 978-91-981535-1-4.

43. Hein, I. (Ed.) The Formation of Cyprus in the 2nd Millennium B.C.: Studies in Regionalism during the Middle and Late Bronze Ages, Proceedings of a Workshop Held at the 4th Cyprological Congress, May 2nd 2008; Österreichischen Akademie der Wissenschaften: Lefkosia, Cyprus; Vienna, Austria, 2009; ISBN 978-3700165460.

44. Frankel, D.; Webb, J.M. Cultural regionalism and divergent social trajectories in Early Bronze Age Cyprus. Am. J. Archaeol. 2013, 117, 59-81.

45. Fall, P.L.; Falconer, S.E.; Galletti, C.S.; Shirmang, T.; Ridder, E.; Klinge, J. Long-term agrarian landscapes in the Troodhos foothills, Cyprus. J. Archaeol. Sci. 2012, 30,1-13. [CrossRef]

46. Webb, J.M. Shifting centres: Site location and resource procurement on the north coast of Cyprus over the longue durée of the Prehistoric Bronze Age. Land 2018, 7, 64. [CrossRef]

47. Keswani, P.S. Models of local exchange in Late Bronze Age Cyprus. Bull. Am. Sch. Orient. Res. 1993, 292, 73-83. [CrossRef]

48. Catling, H.W. Patterns of settlement in Bronze Age Cyprus. Op. Ath. 1962, 4, 129-169.

49. Knapp, A.B. The Archaeology of Late Bronze Age Cypriot Society: The Study of Settlement, Survey and Landscape; University of Glasgow: Glasgow, UK, 1997; ISBN 978-0852615737.

50. Knapp, A.B. Mediterranean maritime landscapes: Transport, trade and society on Late Bronze Age Cyprus. In Res Maritimae: Cyprus and the Eastern Mediterranean from Prehistory to Late Antiquity; CAARI Monograph 1; Swiny, S., Hohfelder, R.L., Wylde Swiny, H., Eds.; ASOR: Atlanta, GA, USA, 1997; pp. 153-162, ISBN 978-0788503931.

51. Steel, L. Exploring regional settlement on Cyprus in the Late Bronze Age: the rural hinterland. In The Formation of Cyprus in the 2nd Millennium B.C.: Studies in Regionalism during the Middle and Late Bronze Ages, Proceedings of a Workshop Held at the 4th Cyprological Congress, May 2nd 2008, Lefkosia, Cyprus; Hein, I., Ed.; Österreichischen Akademie der Wissenschaften: Vienna, Austria, 2009; pp. 135-145, ISBN 978-3700165460.

52. Steel, L. Exploring Aredhiou: New light on the rural communities of the Cypriot hinterland during the Late Bronze Age. Am. J. Archaeol. 2016, 120, 511-536. [CrossRef]

53. Webb, J.M.; Frankel, D. Making an impression: Storage and surplus finance in Late Bronze Age Cyprus. J. Mediterr. Archaeol. 1994, 7, 5-26. [CrossRef]

54. Kling, B.; Muhly, J.D. Joan du Plat Taylor's Excavations at the Late Bronze Age Mining Settlement at Apliki Karamallos 1; Studies in Mediterranean Archaeology 134:1; Åströms Editions: Sävedalen, Sweden, 2007; ISBN 978-9170812262.

55. Knapp, A.B.; Kassianidou, V. The Archaeology of Late Bronze Age copper production. Politiko Phorades on Cyprus. In Anatolian Metal IV; Ünsal, Y., Ed.; Der Anschnitt: Bochum, Germnay, 2008; pp. 135-147, ISBN 978-3-937. 
56. Todd, I.A.; Pilides, D. The archaeology of White Slip production. In The White Slip Ware of Late Bronze Age Cyprus; Karageorghis, V., Ed.; Verlag der Österreichischen Akademie der Wissenschaften: Vienna, Austria, 2001; pp. 27-43, ISBN 978-3700129356.

57. Keswani, P.S.; Knapp, A.B. Bronze Age boundaries and social exchange in north-west Cyprus. Oxf. J. Archaeol. 2003, 22, 213-223. [CrossRef]

58. Casey, E.S. How to get from space to place in a fairly short space of time: Phenomenological prolegomena. In Senses of Place; School for Advanced Research Advanced Seminar Series; Feld, S., Basso, K., Eds.; School of American Research Press: Santa Fe, NM, USA, 1996; pp. 13-52, ISBN 978-0933452954.

59. Finlayson, C. The Improbable Primate: How Water Shaped Human Evolution; Oxford University Press: Oxford, UK, 2014; ISBN 978-0199658794.

60. Roberts, R.G. Human evolution: Just add water. Nature 2014, 507, 303-304. [CrossRef]

61. Attala, L. How Water Makes Us Human; Wales University Press: Cardiff, UK, in press.

62. Mithen, S. Thirst: Water and Power in the Ancient World; Orion Books: London, UK, 2013; ISBN 978-1780226873.

63. Steel, L. Exploring the materiality of water in Bronze Age Cyprus. In Proceedings of the 'Environment, Landscape and Society: Diachronic Perspectives on Settlement Patterns in Cyprus' Conference, CAARI, Nicosia, Cyprus, 17-19 February 2017.

64. Knitter, D.; Blum, H.; Horejs, B.; Nakoinz, O.; Schütt, B.; Meyer, M. Integrated centrality analysis: A diachronic comparison of selected Western Anatolian locations. Quat. Int. 2013, 312, 45-56. [CrossRef]

65. Strang, V. Lording it over the goddess: water, gender and human-environmental relations. J. Fem. Stu. Rel. 2014, 30, 85-109. [CrossRef]

66. Attala, L. Bodies of water. Exploring water flows in rural Kenya. In Exploring the Materiality of Food "Stuffs": Transformations, Symbolic Consumption and Embodiments; Steel, L., Zinn, K., Eds.; Routledge: London, UK, 2017; pp. 79-100, ISBN 978-1138941199.

67. Wilk, R. Water magic. In People at the Well: Kinds, Usages and Meanings of Water in a Global Perspective; Hahn, H.P., Cless, K., Soentgen, J., Eds.; Campus Verlag: Frankfurt, Germany, 2012; pp. 126-144, ISBN 9783593396101.

68. Strang, V. Fluid consistencies. Material relationality in human engagements with water. Archaeol. Dialogues 2014, 21, 133-150. [CrossRef]

69. Peltenburg, E.J. Conclusions. Mylouthkia and the early colonists of Cyprus. In The Colonisation and Settlement of Cyprus: Investigations at Kissonerga Mylouthkia; SIMA 70:4; Peltenburg, E.J., Ed.; Åström Editions: Såvedalen, Sweden, 2003; pp. 3-9, ISBN 978-9170811197.

70. Croft, P. The wells and other vestiges. In The Colonisation and Settlement of Cyprus: Investigations at Kissonerga Mylouthkia; SIMA 70:4; Peltenburg, E.J., Ed.; Åström Editions: Såvedalen, Sweden, 2003; pp. 83-103, ISBN 978-9170811197.

71. Bombardieri, L.; Chelazzi, F.; Amadio, M. Working with water. Procurement, consumption and water-based working activities at Middle Bronze Age Erimi-Laonin tou Porakou (2009-2011 seasons). In Cypriot Cultural Details; Hadjikyriakos, I., Trentin, M.G., Eds.; Oxbow Books: Oxford, UK, 2015; pp. 111-138, ISBN 978-178570-066-8.

72. Rowlett, R.M. Hydrostrategies in southern Luxembourg. In Chalcolithic and Early Bronze Age Hydrostrategies; BAR IS 1123; Gheorghiu, D., Ed.; Archaeopress: Oxford, UK, 2003; pp. 79-84, ISBN 978-1841714998.

73. Calvet, Y. Hydraulic installations at Ugarit. Trav. Maison l'Orient 1981, 2, 33-48. (In French)

74. Calvet, Y. The mastery of water at Ugarit. Comptes Rendus Séances Acad. Inscr. Belles-Lett. Année 1989, 133, 308-326. (In French) [CrossRef]

75. Cadogan, G. Maroni: Change in Late Bronze Age Cyprus. In Late Bronze Age Settlement in Cyprus: Function and Relationship; SIMA PB 126; Åström, P., Herscher, E., Eds.; Åström Editions: Jonsered, Sweden, 1996; pp. 15-22, ISBN 9789170811203.

76. Hitchcock, L. Cultural continuity and regional diversity: The encoding of Aegean form and function in Late Bronze Age Cypriot architecture. J. Preh. Rel. 1999, 13, 11-21.

77. Hadjisavvas, S. Dating Alassa. In The Synchronisation of Civilisations in the Eastern Mediterranean in the Second Millennium B.C.: Proceedings of the SCIEM 2000-EuroConference, Haindorf, 2nd of May-7th of May 2001 II; Bietak, M., Ed.; Austrian Academy of Sciences Press: Vienna, Austria, 2003; pp. 431-436, ISBN 978-3-7001-2936-3. 
78. Devillers, B. Holocene Morphogenesis and Anthropisation of a Semi-Arid Watershed, Gialias River, Cyprus. BAR 1775; Archaeo Press: Oxford, UK, 2008; ISBN 9781407302638.

79. Brown, M.G. Landscapes of Settlement in South-East Cyprus: The Late Bronze Age Origins of a Phoenician Polity. Ph.D. Thesis, University of Edinburgh, Edinburgh, Scotland, UK, 2011.

80. Brown, M.G. Waterways and the political geography of south-east Cyprus in the second millennium BC. Annu. Br. Sch. Athens 2013, 108, 121-136. [CrossRef]

81. Steel, L.; Thomas, S. Excavations at Arediou-Vouppes (Lithosouros), Cyprus; An Interim Report on Excavations 2005-2006; Department of Antiquities Cyprus: Nicosia, Cyprus, 2008; pp. 227-249.

82. Knapp, A.B. Seafaring and seafarers: The case for Late Bronze Age Cyprus. In Structure, Measurement and Meaning: Insights into the Prehistory of Cyprus. Studies on Prehistoric Cyprus in Honour of David Frankel; SIMA 143; Webb, J.M., Ed.; Åström Editions: Uppsala, Sweden, 2014; pp. 79-93, ISBN 978-91-981535-1-4.

83. Wachsmann, S. Seagoing Ships and Seamanship in the Bronze Age Levant; Texas A\&M University Press: College Station, TX, USA, 2008; ISBN 978-1603440806.

84. Sewell, D.A. The seafarers of Maroni. In The Great Islands. Studies of Crete and Cyprus Presented to Gerald Cadogan; Macdonald, C.F., Hatzaki, E., Andreou, S., Eds.; Kapon Editions: Athens, Greece, 2015; pp. 186-191, ISBN 978-9606878-91-6.

85. Hornell, J. The coracles of the Tigris and the Euphrates. Mar. Mirror 1938, 24, 153-159. [CrossRef]

86. Klinge, J.; Fall, P. Archaebotanical inference of Bronze Age land use and land cover in the eastern Mediterranean. J. Archaeol. Sci. 2010, 37, 2622-2629. [CrossRef]

(C) 2018 by the author. Licensee MDPI, Basel, Switzerland. This article is an open access article distributed under the terms and conditions of the Creative Commons Attribution (CC BY) license (http:/ / creativecommons.org/licenses/by/4.0/). 